\title{
COMMENTARY
}

\section{HOW MUCH DOES MONEY MATTER IN A DIRECT DEMOCRACY?}

\author{
JOHN M. DE FIGUEIREDO*
}

The Supreme Court's decision in McConnell v. FEC held that the broad outlines of the Bipartisan Campaign Reform Act passed both legal and constitutional scrutiny. ${ }^{1}$ The McConnell Court agreed with the defenders of the Act that the potential corruptive influence of special interest money in politics was a sufficient rationale for restricting the flow of money in unlimited quantities into candidate campaigns and political parties. ${ }^{2}$ Now the focus of activists has turned to ballot initiative and referendum campaigns. These groups have argued that the tight relationship of candidates to particular ballot initiatives creates the same corruptive influence that concerned the Court in candidate elections. ${ }^{3}$ Thus, there is an increasingly loud call for restrictions on ballot campaign financing. ${ }^{4}$

It would seem, however, that before we heed calls for legislatively or judicially imposed restrictions on ballot measure financing, it would be prudent to know the effect of such financing on ballot outcomes. Knowing

* Fellow in Law and Public Affairs, Woodrow Wilson School, Princeton University, and John M. Olin Senior Visiting Fellow in Law and Economics, Harvard Law School. I wish to thank Beth Garrett, Chang-Ho Ji, Jonathan Katz, Thad Kousser, John Matsusaka, Nolan McCarty, and participants of the Symposium of the Impact of Direct Democracy, January 15, 2005, for helpful conversations and comments.

1. McConnell v. FEC, 540 U.S. 93 (2003).

2. For a lengthy discussion of this point, see John M. de Figueiredo \& Elizabeth Garrett, Paying for Politics, 78 S. CAL. L. Rev. 591 (2005).

3. See Richard L. Hasen, Rethinking the Unconstitutionality of Contribution and Expenditure Limits in Ballot Measure Campaigns, 78 S. CAL. L. REV. 885, 897-907 (2005).

4. See id. at 910-11 (discussing the efforts by scholars and activists to limit ballot measure financing). 
the effect of money in ballot measure campaigns would not only provide legal scholars with an important piece of information regarding whether restrictions on money are warranted, but it would also aid in the construction of those restrictions should they be needed. This short paper provides an overview of the statistical literature examining the effect of money on ballot measure outcomes and analyzes the validity of the statistical analyses.

Social scientists have examined the question of ballot financing from a statistical perspective for over a decade. The canonical regression which is run is as follows:

$$
\text { Vote Share } i=\beta_{0}+\beta_{1}\left(\text { SFor }_{i}\right)+\beta_{2}\left(\text { SAgainst }_{i}\right)+\gamma \mathbf{X}_{i}+\varepsilon_{i}
$$

where the dependent variable, Vote Share, is some measure of the ballot measure $i$ 's outcome (such as the share of the winning vote), \$For is the amount of money spent in the campaign by proponents of the measure, \$Against is the amount of money spent in the campaign against the ballot initiative, and $\mathbf{X}$ is a matrix of variables related to the ballot question, such as the characteristics of the measure or the election, and $\varepsilon_{i}$ is the error term. The parameters $\beta_{1}, \beta_{2}$, and $\gamma$ measure the effect of the independent variables on the dependent variable ${ }^{5}$ and are estimated by the regression analysis.

Many scholars have run the above regression, and the result has largely been the same across authors-namely that $\beta_{1}$ (though often having a negative coefficient) is not statistically different from zero, while $\beta_{2}$ is negative and statistically significant. ${ }^{6}$ That is, money spent against initiatives has an effect in reducing support for the ballot question, but money spent for an initiative has no statistical effect in increasing vote share (and may actually diminish support for the ballot question). Arthur Lupia and John Matsusaka summarized the current wisdom on ballot measure campaign finance as follows:

The general finding [in the literature] was that heavy spending against a measure tended to lead to the measure's defeat, whereas heavy spending

5. $\beta_{0}$ is the constant.

6. See Shaun Bowler \& Todd Donovan, Demanding Cholces: Opinion, Voting, and

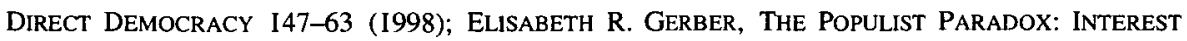
Group INFLUENCE AND the PRomise of DiRect LeGiSLATION IOI-20 (1999); Elizabeth Garrett \& Elisabeth R. Gerber, Money in the Initiative and Referendum Process: Evidence of Its Effects and Prospects for Reform, in THE BATTLE OVER CITIZEN LAWMAKING 73, 85-87 (M. Dane Waters ed., 2001); Chang-Ho C. Ji, California's Direct Democracy 1976-1998: Predictors, Outcome, and Issues (I998) (unpublished manuscript presented at the Western Political Science Association Annual Meeting, 1998, on file with author). 
in favor of a measure had minimal effect. That basic finding has held up well in studies using more sophisticated techniques. ${ }^{7}$

This result raises serious questions. If these results are correct, why is the effect of spending on outcomes asymmetric? Moreover, why would anyone spend in support of the initiative if there is no, or even a negative, effect? The problem in this result lies in the fact that the analysis to date is likely incomplete. There are certainly factors omitted from the analysis that appear in the error term, $\varepsilon_{i}$, that are correlated with the amount spent for and against the ballot initiative. For example, money is more likely to be spent when polling shows that the vote on a ballot measure is likely to be close. If a ballot measure has widespread support, there is little need to spend money; if a ballot measure is very unpopular, there is, again, little need to spend money, as the measure will likely fail. The problem in this specification of the regression is that the amount of money spent for and against a given ballot question is an endogenous choice variable that must be modeled, and not an exogenous variable as is assumed in the ordinary least squares regression that many previous authors have used. If one does not take into account this endogeneity, manifested by a correlation of the error term and the spending variables, the regression analysis will generate biased coefficients.

Thomas Stratmann, in his article The Effectiveness of Money in Ballot Measure Campaigns, recognizes this precise methodological problem in the literature. ${ }^{8}$ He very nicely explains the endogeneity and omitted variable bias problems that have plagued the empirical statistical literature on ballot questions to date. In his article, Stratmann seeks to correct the recurring statistical problems in the literature.

Rather than use a dataset on overall ballot question spending, Stratmann uses a dataset on the number of television advertisements and the amount spent on television advertising by the supporters and opponents of eighteen ballot questions in California from 2000 to 2004. In addition, Stratmann examines advertising on the county level, rather than on the state level as previous papers have done. In doing this, Stratmann is not only able to exploit cross-county variation in the data, but he is able to focus only on attempts by advocates and detractors to persuade the electorate through advertising on television. To control for the endogeneity and

7. Arthur Lupia \& John G. Matsusaka, Direct Democracy: New Approaches to Old Questions, 7 ANN. ReV. POL. SCl. 463, 470 (2004) (citing Garrett \& Gerber, supra note 6).

8. Thomas Stratmann, The Effectiveness of Money in Ballot Measure Campaigns, $78 \mathrm{~S}$. CAL. L. REV. 1041, 1055-55 (2005). 
omitted variable bias problem, the article uses county and ballot measure fixed effects.

Stratmann's findings are striking. First, using this data and controlling for the methodological problems as he does, he finds that both television advertising spending in support and against a ballot question have a statistically significant effect on the vote shares. That is, contrary to the previous literature, the article demonstrates both that $\beta_{1}$ is positive and statistically significant and that $\beta_{2}$ is negative and statistically significant. He also measures the substantive effect of money. He finds that the results imply that "100 extra advocacy television advertisements increase the ballot's vote percentage [in a county] by 1.2 percentage points, and the same number of opposition advertisements decreases this percentage by 0.6 percentage points." 9 In explaining his finding, he notes that advocacy advertising is twice as effective as opposition advertising on a dollar-fordollar basis.

Note, however, that this substantive effect is somewhat small. The article shows that on average, 428 advocacy advertisements and 190 opposition advertisements occur in a given county during a given ballot initiative. ${ }^{10}$ Thus, 100 extra advertisements represents a $23 \%$ increase in advocacy advertising and $53 \%$ increase in negative advertising. Cast in this light, the effects that Stratmann finds in his article, though statistically significant, are quite small: a $23 \%$ increase in advocacy advertisements increases vote share by 1.2 percentage points, wbile a $53 \%$ increase in opposition advertisements decreases vote share by only 0.6 percentage points.

The fundamental question for the Stratmann analysis, however, is how well the county's and ballot initiative's fixed effects control for the endogeneity and omitted variable bias problems.

Yair Mundlak demonstrated theoretically that fixed effects can solve the endogeneity and omitted variable bias problems when the nature of endogeneity is specific to the actor and time-invariant. ${ }^{11}$ In the context of Stratmann's article, this would mean that county fixed effects solve the statistical problem if the willingness to support any given ballot measure by a county is time invariant. While one may reasonably believe that

9. Id. at 20; Stratmann, supra note 8, at 1055.

10. Id. at 1055 .

11. Yair Mundlak, Estimation of Production and Behavioral Functions from a Combination of Cross-Section and Time-Series Data, in MEASUREMENT IN ECONOMICS: STUdiES IN MATHEMATICAL ECONOMICS AND ECONOMETRICS 138 (1963). 
preferences in a given county do not change appreciably over a four year period, ${ }^{12}$ county fixed effects will not solve the endogeneity problem if there is heterogeneity in underlying preferences for the status quo across ballot measure type within a county.

This is perhaps best explained by an example. Assume a Republicandominated county and imagine two types of ballot measures: one to cut taxes and one to substantially increase taxes. In the main results of Stratmann's article, the county has an underlying willingness to keep the status quo (or conversely, an underlying willingness to pass any given ballot measure). The county fixed effects imply that this county has an equal underlying willingness (because of preferences) to pass both of these measures and that advertising will be targeted in such a way to maximize the outcome. But clearly, in this example, the underlying willingness of this Republican county to pass tax cuts will be much higher than the underlying willingness of this county to pass substantial tax increases. That is, the underlying willingness of county $j$ to pass ballot measure $i$ will differ across ballot measures. County fixed effects will not solve the omitted variable and endogeneity problems if measures are of different types. Although preferences are time invariant within a county, the status quo bias of a county (or underlying willingness to pass any given ballot initiative) changes from ballot question to ballot question.

One natural reply to this critique is that the ballot fixed effects with county fixed effects solve this problem. Ballot fixed effects, the argument goes, will control for differences in ballot measures and allow us to solve the omitted variable bias problem. This argument, while appealing, is likely incomplete. Ballot fixed effects only allow one to control for differences in spending across counties within a ballot issue.

We can return to our example. Suppose we have our ballot measure to cut taxes. Democratic counties will be more likely to vote against the measure; Republican counties will be more likely to vote for the measure. If on the other hand, our ballot measure proposes to raise taxes, the opposite will be true. Ballot fixed effects do not allow us to identify how different counties react to different ballot measures, only how different counties react to the same ballot measure.

12. Note that during the sample frame, the September 11 attacks occurred, there was a financial crisis in California, the Governor was recalled, and a new Governor was elected. It is quite plausible that even within a county in California, there were large changes in preferences during this time because of these exogenous events. 
To summarize, the problem is that county fixed effects control for differences in counties. Ballot fixed effects controls for differences in ballot questions. What is really needed here is to control for dimension $i$ (ballot measures) and $j$ (counties) simultaneously. One method of solving this is to interact all the county fixed effects with all the ballot fixed effects (for all combinations). This would allow one to control for the $i$ and $j$ dimensions simultaneously. Of course, this is infeasible because there are not enough degrees of freedom to estimate the parameters of such a model.

When faced with this problem, there are two practical ways to solve it. The first is to characterize the ballot initiatives according to underlying characteristics that are linked to the preferences for the status quo. For example, one could characterize the ballot questions as "conservative" or "liberal." Then, separate regressions can be run for the liberal and conservative measures. The willingness of a given voter to keep the status quo will be directly related to his or her preferences relative to the ideological leaning of the ballot measure. One can then examine how campaign spending will affect the willingness of a voting bloc, which is a given ideological distance from a ballot measure, to change the status quo.

This is precisely what Stratmann does in extensions to his analysis presented in Table $3 .{ }^{13}$ In a creative measure of the ideological makeup of a ballot measure, Stratmann uses the voting recommendations of the Los Angeles Times to determine whether an initiative is liberal or conservative. ${ }^{14} \mathrm{He}$ then replicates his analysis and finds results similar to his previous analysis, though every dollar of advocacy advertising is then nearly three times as productive at determining the vote outcome as a dollar of opposition advertising.

13. Stratmann, supra note 8 , at 1057 tbl.3.

14. See Tim Groseclose \& Jeff Milyo, A Measure of Media Bias (Dec. 2004) (unpublished manuscript, on file with author), available at http://www.polisci.ucla.edu/faculty/groseclose/ MediaBias.pdf. Tim Groseclose and Jeff Milyo have developed an ideology score for a number of major media outlets, including the Los Angeles Times. They found that the Los Angeles Times is a liberal-leaning newspaper. See id. at 39-40 tbls.3, 4. Stratmann examines his eighteen ballot measures and determines whether the Los Angeles Times recommends supporting or opposing the measure. If the Los Angeles Times supports the measure, it is considered liberal; if the Los Angeles Times opposes the measure, it is considered conservative. One small caution must be sounded. The Groseclose and Milyo scores refer to the ideological leaning of the news stories, not the editorial pages. Their study found, for example, that the news stories in the Wall Street Journal are quite liberal, even though its editorial pages are conservative. Thus, the added assumption in the Stratmann article is that the Groseclose and Milyo scores for news represent the ideological leanings of the editors of the newspaper who make the voting recommendations. This caveat, however, does not diminish the creativeness of the Stratmann approach. 
While quite creative, and certainly a leap in the statistical analysis of ballot measure spending, even this analysis can at times have shortfalls. In particular, it bifurcates the analysis into liberal and conservative initiatives, but some initiatives may not be "liberal" or "conservative." For example, some "conservative" counties may be very willing to support gambling but not term limits, while other "conservative" counties may be willing to support term limits but not gambling. Thus, while the liberal and conservative labels do indeed buy us some traction on the problem, it is not a complete solution because it does not allow for strategic spending by allowing both $i$ and $j$ to vary simultaneously.

This then leads to our second method to solve this problem: instrumental variables in a two stage regression. Instrumental variables are variables that are correlated with $\$$ For or $\$$ Against in this case, and uncorrelated with the error term, $\varepsilon$. In more concrete terms, we seek variables that are directly correlated with \$For and \$Against, but are uncorrelated with the outcome of the vote on the ballot question (except through the spending variables). In the first stage, the researcher regresses $\$ F$ or or \$Against on a series of independent variables, including the instrumental variable. This generates predicted values for the amount of money spent. In a second stage regression, the researcher then regresses the vote outcome on the predicted spending levels (from the first stage equation) and a series of independent variables to generate unbiased estimates of the effect of spending on vote outcome. One attractive feature of good instrumental variables is that they vary in both $i$ and $j$ simultaneously. Another way of saying this, in the context of the Stratmann article, is that they would vary across county and ballot initiative simultaneously, thus solving the omitted variable bias problem.

The challenge for scholars is to find good instruments. Good instruments are very difficult to find because the instrument must be directly correlated with spending but not directly correlated with ballot outcomes. In a work in progress, however, by John de Figueiredo, Chang $\mathrm{Ho} \mathrm{Ji}$, and Thad Kousser, instruments are being developed. ${ }^{15}$ In this project, the authors examine California ballot measures between 1976 and 1998 where there has been spending on both sides of the ballot question at

15. John M. de Figueiredo, Chang-Ho Ji \& Thad Kousser, Why Do Initiative Backers Waste Their Money? Revisiting the Research on Campaign Spending and Direct Democracy (Apr. 2005) (unpublished manuscript presented at the Conference on Direct Democracy in the West: Historical Roots and Political Realities, Stanford University, April 14-15, 2005, on file with author). 
the state level. ${ }^{16}$ Recognizing the same endogeneity and omitted variable bias problem as Stratmann, the authors have developed an instrumental variables approach to the problem. One set of possible instruments is to identify the scope and size of economic benefit and cost to industry of the ballot measure. ${ }^{17}$ For example, take California Proposition 1A, which allows the governor to negotiate directly with Indian tribes to expand their gambling operations. With such authority, the governor will likely allow Indian tribes to substantially expand their profitable gambling operations in California. ${ }^{18}$ The benefit to Indian tribes will be fairly large (estimated in the billions of dollars) and very concentrated (a handful of Indian tribes will see most of the benefit of the proposition). Although others may benefit, the bulk of the benefit accrues to the Indian tribes. This suggests Indian tribes and casinos will have a strong incentive to spend money in support of the proposition because they are able to overcome a serious collective action problem.

The willingness and ability of corporations and business entities to overcome the collective action problem is likely to be correlated with the amount of money spent either for or against a ballot initiative, but is unlikely to be directly correlated with the vote outcome (except through the spending mechanism) because corporations do not vote. Thus, this would seem to be a good candidate for an instrumental variable. In their work, de Figueiredo, Ji, and Kousser have used instrumental variables to examine the effect of spending on ballot outcomes. The initial results are mixed on the validity of these instruments. Despite this, the overall results of the instrumental variables analysis are broadly consistent with the Stratmann findings. Although the authors' work is still in progress, this project illustrates that instrumental variables to control for ballot measure campaign spending, while difficult to identify, are not entirely elusive.

Stratmann is one of the academic leaders in the study of campaign finance. It would be difficult to write a paper on the subject without citing his work. His recognition of the endogeneity and omitted variable bias problem in the literature on ballot measures is a substantial contribution to the literature. This problem has plagued all previous work in the field (that I have examined). His approach of using fixed effects to address this

16. See id. at 15-16. While the authors do develop instrumental variables at the state level, they would not be valid at the county level as would be required in the Stratmann dataset. Nevertheless, they do provide some guidance as to how one might think about new instruments.

17. See id. at 17-18.

18. The state will likely receive substantial tax revenue from any compact, but Indian tribes will also likely see substantial surplus despite the taxes. 
problem provides a partial solution. His extension of separating the liberal and conservative measures provides a more complete solution. These methodological innovations in the empirical analysis on ballot measure financing are vast leaps in understanding how money affects ballot measure outcomes. A fixed effects approach with instrumental variables, however, will allow us to address this problem more comprehensively and would seem to be a worthy goal for scholars of this literature. ${ }^{19}$ More generally, papers that recognize the omitted variable bias and endogeneity problem in the literature and attempt to correct it will raise the debate on campaign finance on ballot measures to a much higher level and allow more serious discourse on the subject to guide the Supreme Court's rulemaking. We can only encourage this kind of work to determine how much money truly matters in a direct democracy.

19. Stratmann is clearly a proponent of this agenda. See Stratmann, supra note 8, at 1052 n.43, 1061 . 
